\title{
An Evaluation of William James' Pragmatic Concept of Truth
}

\section{Anetoh Bonaventure Chike (Ph.D)}

Department of Philosophy and Religious Studies, Tansian University, Umunya, Nigeria.

Email: anetohbonaventure@yahoo.com; Phone no: +234-08067703185

\section{Cite this article:}

Anetoh Bonaventure Chike (2021), An Evaluation of William James' Pragmatic Concept of Truth. African Journal of Social Sciences and Humanities Research 4(4), 1121. DOI: $10.52589 / A J S S H R-$ RA80JGIL.

\section{Manuscript History}

Received: 14 July 2021

Accepted: 7 Aug 2021

Published: 21 Aug 2021

Copyright (c) 2020 The Author(s). This is an Open Access article distributed under the terms of Creative Commons AttributionNonCommercial-NoDerivatives 4.0 International (CC BY-NC-ND 4.0 ), which permits anyone to share, use, reproduce and redistribute in any medium, provided the original author and source are credited.

\begin{abstract}
This article focuses on an evaluation of William James' pragmatic concept of truth. Pragmatism is one of the contemporary schools of thought or movements in philosophy. It emphasizes the practical aspects of ideas or theories. Among the basic issues in pragmatism is the issue of truth. The basic questions are: What is pragmatism? How does William James conceive truth in his pragmatic theory? Is truth objective or relative? Is truth static or ever-changing? Is there any relationship between truth and practical consequences of things? Is truth intrinsic or extrinsic to an idea? These and other related issues are the major focus of this article. William James, in his pragmatism, approaches truth from the perspective of its practical consequence, and argues that truth 'happens' to an idea. The researcher argues that though William James' pragmatic concept of truth is associated with some problems, he has made outstanding contributions to scholarship by bringing out the practical implications of truth, and extricating it from rationalistic tendency as well as dogmatism.
\end{abstract}

KEYWORDS: Pragmatism, Truth, Relativism, Practical 


\section{INTRODUCTION}

The concept of truth is a very fundamental and important concept in epistemology. Epistemology is the branch of philosophy that examines the validity and justification of human knowledge. Basically, knowledge has to do with 'truth'. In fact, truth occupies a central position in human knowledge. What one claims to know ought to be true in order to be properly called knowledge. The quest for certitude of knowledge is an attempt to demonstrate beyond reasonable doubt the truth of our knowledge. The basic question is this: 'What actually is truth'? This question occupies a prominent position in epistemology. Just as in many other philosophical issues, the concept of truth is a very controversial issue among epistemologists. They have varied, and even conflicting views on what it is all about. Attesting to this lack of consensus on the concept of truth, Eboh (1995) states thus: "Among philosophers, there is no general agreement about the definition of truth. In the main, there are three definitions or theories of truth based on realist, idealist and pragmatic view-points." (pp.40-41) This, as pointed out by Eboh (1995), gave rise to three classical theories of truth, viz. correspondence, coherence and pragmatic theories of truth. The thrust of this study is not to examine all these attempts to explain what truth is all about, but rather to focus only on the pragmatic concept of truth as articulated by William James, and at the same time attempt an evaluation of it. It ought to be noted that Charles Sanders Peirce, William James and John Dewey are the pioneer proponents of pragmatism as a philosophical orientation. They criticized correspondence theory of truth which claims that a true idea is the one that corresponds to reality, and insist that a true idea is the one that yields a successful result in human action. Particularly, one of the major issues that William James addressed in his pragmatic theory is the issue of truth. He considered the pragmatic theory of truth as fundamental to the pragmatic school of thought.

Pragmatic view of truth claims that an idea is true if it is workable or leads to successful results. In our society today, many people accept certain ideas as true because such ideas have led to successful actions. The questions that are very necessary in this article are: Is there any property in an idea that makes it objectively true? Can one talk of objective truth? Is truth intrinsic or extrinsic to an idea? Is an idea said to be true because it is successful in practice? These and other related issues are to be given due attention in this article as the researcher evaluates William James' pragmatic concept of truth.

This article is divided into four major sections. The first section analyses the concept of pragmatism and truth. The second section examines the general pragmatic concept of truth. The third section focuses specifically on William James' pragmatic concept of truth. The fourth section is the evaluation as well as the conclusion of the article.

\section{Conceptual Analysis}

This section focuses on conceptual analysis of the key or basic concepts in the topic of discussion in this article. The basic concepts are: Pragmatism and Truth

\section{The Concept of Pragmatism:}

Since the major concern of this article is William James' pragmatic concept of truth, there is a need to briefly examine the concept of pragmatism. This enables one to appreciate William James' pragmatic concept of truth. Pragmatism is one of the contemporary orientations or schools of thought in philosophy. It originated in the late 19th century in the United States of 
America. It was Charles Sanders Peirce who initiated pragmatism, but it was made popular by William James. According to Maddux and Donnect (2015):

Although Peirce is recognized as the founder of American pragmatism, the term itself was not employed in writing until 1898, when William James, in a speech delivered at Berkeley entitled "Philosophical Conceptions and Practical Results," claimed that he first heard Peirce enunciate the principles of "practicalism — or pragmatism, as he called it" at Cambridge in the 1870 s...(p.65)

Etymologically, the word 'pragmatism' was derived from the Greek word "pragma," which means 'action' or 'deed'. From its etymological perspective, it is easily noticeable that pragmatism is 'action oriented'. It emphasizes 'praxis' as against mere theory or idea.

Charles Sanders Peirce, William James, John Dewey, Jane Addams, George Herbert Mead etc. were the founding fathers of pragmatism as a philosophical orientation. Legg and Hookway (2020) articulate the contributions of each of the founding fathers in the development of pragmatism thus:

Pragmatism originated in the United States around 1870, and now presents a growing third alternative to both analytic and 'Continental' philosophical traditions worldwide. Its first generation was initiated by the so-called 'classical pragmatists' Charles Sanders Peirce (1839-1914), who first defined and defended the view, and his close friend and colleague William James (1842-1910), who further developed and ably popularized it. A second (still termed 'classical') generation turned pragmatist philosophy more explicitly towards politics, education and other dimensions of social improvement, under the immense influence of John Dewey (1859-1952) and his friend Jane Addams (18601935)... Also of considerable importance at this time was George Herbert Mead (1863-1931), who contributed significantly to the social sciences, developing pragmatic perspectives upon the relations between the self and the community... (para. 2)

These classical pragmatists articulated different, but related versions of pragmatism. They contributed in different ways towards the development of pragmatism as a philosophical orientation in the contemporary period of philosophy. Stumpf (1994) notes that "what united them was their conviction that there must be a close connection between thinking and doing." (p.383) This portrays their interest in practical aspects of our lives as human beings. It ought to be noted that the emphasis on the connection between thinking and action is the central point of pragmatism as a philosophical movement.

Pragmatism rejects rationalism, and it is quite related to empiricism. In fact, pragmatism could be said to be an offshoot of empiricism. James (1991) brings out the relationship between pragmatism and empiricism thus: 
Pragmatism represents a perfectly familiar attitude in philosophy, the empiricist attitude, but it represents it, as it seems to me, both in a more radical and in a less objectionable form than it has ever yet assumed. A pragmatist turns his back resolutely and once for all upon a lot of inveterate habits dear to professional philosophers. He turns away from abstraction and insufficiency, from verbal solutions, from bad a priori reasons, from fixed principles, closed systems, and pretended absolutes and origins. He turns towards concreteness and adequacy, towards facts, towards action and towards power. That means the empiricist temper regnant and the rationalist temper sincerely given up. It means the open air and possibilities of nature, as against dogma, artificiality, and the pretence of finality in truth.( p.25)

From the foregoing, it becomes very clear that pragmatism has its unique ideas that distinguish it from other philosophical schools of thought. Fundamentally, pragmatism emphasizes the practical consequence or the usefulness of ideas or hypotheses. Hence, any good idea must have practical consequences. This enables pragmatism to settle metaphysical disputes. Thus, pragmatism becomes the method of settling interminable metaphysical disputes: James (1991) expresses this very well when he notes that:

The pragmatic method is primarily a method of settling metaphysical disputes that otherwise might be interminable. Is the world one or many? - fated or free? - material or spiritual? - here are notions either of which may or may not hold good of the world; and disputes over such notions are unending. The pragmatic method in such cases is to try to interpret each notion by tracing the respective practical consequences. What difference would it practically make to any one if this notion rather than that notion were true? If no practical difference whatever can be traced, then the alternative mean practically the same thing, and all dispute is idle. Whenever a dispute is serious, we ought to be able to show some practical difference that must follow from one side or the other being right. (p.23)

Obviously, one can't talk of pragmatism without making reference to experience or practical implication of ideas or theories. Such reference to experience or practical implication of ideas distinguishes pragmatism remarkably from rationalism, and at the same time establishes its relationship with empiricism. What is necessary in each idea or word, as far as pragmatism is concerned, is its 'practical cash-value'. Certainly, the emphasis on 'practical cash-value' of any idea or word brings out very clearly the outstanding contribution of pragmatism to the world of knowledge.

In the main, pragmatism argues and insists that every hypothesis or idea must be related to praxis. Human thoughts or thinking processes are intrinsically linked to action, and should definitely end in action. This implies that any human thought that does not terminate in action is fundamentally meaningless. In other words, it is action that gives meaning to ideas. "The argument could be made that pragmatism represented an attempt to justify or to provide the grounds for theoretical thinking, requiring only that thought terminates in action of some sort." 
(Stumpf, 1994, p.384). The point pragmatism wishes to emphasize is that the meaning of human action as well as belief is to be found in their consequences.

What matters for pragmatists is basically the fruit or consequence of ideas or actions. This is as a result of their firm conviction that reality is not static, but is rather ever changing. Things change at every turn of events. Pragmatists agree with Heraclitus that nothing is static, but that everything is subject to change. This implies that it is impossible for one to experience exactly the same situation more than once. For them, the world is changing, and such is possible through actions. Pragmatists interpret human action from the perspective of the situation or context in which it occurs. More importantly, they assess human actions with reference to their consequences. Hence, actions are considered good if they lead to favourable or successful consequences. In a similar way, an idea or hypothesis is considered true if it has favourable or successful practical consequences.

\section{The Concept of Truth}

As was already demonstrated in the introductory part of this article, truth is a fundamental concept in Epistemology. Also, truth is one of the issues that received serious scholarly attention from pragmatists. Generally, truth could be said to be a very common concept in the sense that people often make use of the term 'truth' in their conversations. The meaning of truth seems to appear very simple and straight-forward to an ordinary man who has little or no knowledge of Epistemology. This stems from the fact that such an ordinary man thinks that he can distinguish what is 'true' from what is 'not true'.

However, in the domain of Epistemology, the concept of truth is not as simple as it seems to be. It is a very difficult concept to define because of its ambiguous nature. It is also a controversial concept. The basic questions are: What is it that makes something to be true? What does it mean to say that something is true? What are the conditions for truth? Is truth objective or relative? These questions are scholarly and very necessary because the responses to them can enable one to articulate what truth is all about. In the attempt to define truth, philosophers came up with varied and conflicting views. Eboh (1995) identified three different approaches to the definition of truth which gave rise to the three classical theories of truth, viz. correspondence, coherence and pragmatic theories of truth. Each of these theories of truth made an attempt to articulate what truth is all about. Correspondence theory of truth represents the view of realists such as Aristotle and Thomas Aquinas who maintain that "truth is the conformity of the intellect (judgement) to the object known" (Eboh, 1995, p.41) Many scholars view truth from this perspective. Paul Horwich, as cited by Jimoh (2017) defines truth from the realist's view-point as "the quality of those propositions that are in accord with reality, specifying what is in fact, the case. (p.122) From this perspective, something is said to be true if it agrees with objective reality. The realists' view of truth was criticized by idealists like Plato, Hegel, Royce etc who came up with Coherence theory of truth which argues that "since there is no room for a correlation of propositions with reality, truth can exist only in the coherence of the body of propositions with each other." (Eboh, 1995, p. 42) A true idea, for this theory, becomes an idea that agrees or that is consistent with other true ideas. However, pragmatists have a quite different view of truth, which differs essentially from those of the realists and idealists. For the pragmatists like Charles Sanders Peirce, William James and John Dewey etc., "an idea or a theory or a hypothesis is true if it works out in practice, if it leads to satisfactory results." (Eboh, 1995, p.45) This view questions fundamentally the objectivity of 
truth, and argues constantly that nothing is intrinsically true. Hence, truth is not inherent in an idea or theory.

Obviously, each of these different approaches or theories of truth has its limitations or shortcomings. These notwithstanding, they give us insights towards understanding the concept of truth. It ought to be noted that lack of agreement on the concept of truth demonstrates the fact that truth is not a simple concept, but rather remains a very controversial one.

However, the major focus of this article is the pragmatic concept of truth with particular reference to William James. Before delving into the analysis of William James' pragmatic concept of truth, it is scholarly necessary to first of all examine the general pragmatic concept of truth. This enables one to place William James' pragmatic concept of truth into its proper context.

\section{PRAGMATIC CONCEPT OF TRUTH}

The previous sections of this article examined the concepts of pragmatism and truth respectively. Hence, the ground is now scholarly fertile for the analysis of pragmatic concepts of truth. Also, it is pertinent to discuss the general pragmatic concept of truth before narrowing attention to William James' pragmatic concept of truth.

The concept of truth is among the basic concepts that occupied the attention of pragmatists. Pragmatism offers us a unique understanding of truth which is quite different from other theories of truth. Pragmatic concept of truth can be traced back to Charles Sanders Peirce. According to Capps (2019):

Pragmatic theories of truth are usually associated either with C.S. Peirce's proposal that true beliefs will be accepted "at the end of inquiry" or with William James' proposal that truth be defined in terms of utility. More broadly, however, pragmatic theories of truth focus on the connection between truth and epistemic practices, notably practices of inquiry and assertion. Depending on the particular pragmatic theory, true statements might be those that are useful to believe, that are the result of inquiry, that have withstood ongoing examination, that meet a standard of warranted assertibility, or that represent norms of assertoric discourse. Like other theories of truth (e.g., coherence and deflationary theories) pragmatic theories of truth are often put forward as an alternative to correspondence theories of truth. Unlike correspondence theories, which tend to see truth as a static relation between a truth-bearer and a truth-maker, pragmatic theories of truth tend to view truth as a function of the practices people engage in, and the commitments people make, when they solve problems, make assertions, or conduct scientific inquiry. (para. 1)

It is obvious that it was Charles Sanders Peirce that initiated the pragmatic concept of truth. William James played a prominent role in popularizing the pragmatic concept of truth, and "suggests that true beliefs can be satisfying short of being indefeasible and unassailable: short, 
that is, of how they would stand up to ongoing inquiry and investigation." (Capps, 2019, para. 8) Other pragmatists have varied but related ideas on the concept of truth. Generally, pragmatists regard truth as a relative concept. This implies that truth is not an absolute concept. Hence, nothing is absolutely true. It can change from time to time. They argue that truth is related to experience, and can change just as people's experience can change.

\section{WILLIAM JAMES' PRAGMATIC CONCEPT OF TRUTH}

William James is one of the classical pragmatists. He was deeply influenced by Charles Sanders Peirce's pragmatic ideas, though he developed a new approach to pragmatism. In his pragmatic theory, he gave serious and detailed attention to the issue of truth. This section of the article focuses on examining William James' pragmatic concept of truth. He argues that truth is not intrinsic in an idea, but rather is external to it. Hence, an idea is true if it makes a positive concrete difference in actual life. According to James (1991):

Pragmatism, on the other hand, asks its usual question. "Grant an idea or belief to be true," it says, "what concrete difference will its being true make in any one's actual life? How will the truth be realized? What experiences will be different from those which would obtain if the belief were false? What, in short, is the truth's cash-value in experiential terms?" The moment pragmatism asks this question, it sees the answer: True ideas are those that we can assimilate, validate, corroborate and verify. False ideas are those that we cannot. That is the practical difference it makes to us to have true ideas; that, therefore, is the meaning of truth, for it is all that truth is known-as. (pp.88-89)

This implies that an idea is not in itself to be considered as being true or false. It becomes true as a result of its consequences. In other words, the consequence of an idea is the determinant of its truth value. Thus, truth is not a fixed quality or property of ideas or theories. James (1991) further argues that "the truth of an idea is not a stagnant property inherent in it. Truth happens to an idea. It becomes true, is made true by events." (p.89) Furthermore, William James insists that there is a relationship between truth and action. In fact, a true idea ought to be connected to action. Any idea that is not related to action cannot be said to be a true idea.

From the foregoing, it is clear from William James' perspective that 'action' is a very necessary determinant of the truth value of an idea. Truth becomes action-oriented. Hence, James' concept of truth differs remarkably from both correspondence and coherence theories of truth. Analyzing William James' pragmatic concept of truth, and articulating how it differs from other theories of truth, Stumpf (1994) notes:

James made the startling statement that "truth happens to an idea." What was so startling about this statement was that the more traditional theories of truth took virtually the opposite view, namely, that truth is a property or quality of an idea. James was rejecting what he called the copy-view of truth. This theory assumes that an idea "copies" reality, and an idea is therefore true if it copies what is "out there" accurately. 
Truth is that quality an idea has when it copies accurately...Against this theory, James brought the whole arsenal of his pragmatism. Truth must be the cash value of an idea. (p.390)

Furthermore, James interprets truth with reference to experience, and as such truth changes just as one's experiences change. There is a deep relationship between truth and experience. Thus, he brought out very clearly the non-static nature of truth. It changes under different circumstances. This agrees with the Heraclitean principle that change is constant in life. In an attempt to respond to James' idea of the relationship between truth and experience as well as the ever-changing nature of truth, Pomerleau (n.d) states:

$\mathrm{He}$ is a fallibilist, seeing all existential truths as, in theory, revisable given new experience. They involve a relationship between facts and our ideas or beliefs. Because the facts, and our experience of them, change we must beware of regarding such truths as absolute, as rationalists tend to do (para. 16)

One can easily observe that James deviated completely from the realists' notion of truth as conformity of an idea with objective reality. The interesting and unique aspect of James' concept of truth is that he brought out the practical aspect of truth by relating it to action or event. The view that truth happens to an idea implies that truth does not exist intrinsically in an idea. It is external to it. Hence, an idea becomes true if it is successful in practical life. Any idea that does not lead to successful action is not a true idea. The successfulness of an idea determines its truth value. The implication of William James' idea that the truth of an idea is determined by its successfulness in practical life is that the truth of an idea is not just one, but may be many if it leads to many successful actions.

On this theory, says James, there are as many plural truths as there are concrete successful actions. Moreover, James would say that truth is bound up with the personal interests of concrete individuals. By this he meant that truth is not something capricious. As bound up with personal interests, the "truth" must lead to successful action: it must work. In the long run a true belief must work beneficially, just as an "untrue" one will work destructively. (Stumpf, 1994, p.391)

Obviously, James' pluralistic idea of truth is very controversial, and thus has been an object of severe criticisms. There is a need at this juncture to evaluate William James' concept of truth in order to unravel its strengths and weaknesses.

\section{EVALUATION}

The researcher has made an effort in this article to examine the pragmatic concept of truth in general, and William James' pragmatic concept of truth in particular. It ought to be noted that William James and other pragmatists have made important contributions to knowledge by emphasizing the practical aspect of truth as well as practical consequences of ideas. However, William James' pragmatic concept of truth is associated with some problems. Such problems 
necessitated severe criticisms of James' pragmatic idea of truth. By insisting that truth 'happens' to an idea, and by affirming that truth is not a permanent quality of an idea, William James and other pragmatists have denied the objectivity of truth as well as the static nature of truth. This implies that nothing is objectively true, and thus the truth value of an idea is ever changing. Such belief leads to relativism. Attesting to this, Eboh (1995) states:

Criticism of this theory centres on relativism and what the critics called happy illusion-Relativism in that if truth is defined in terms of utility, workability and successful result, there is the danger that there can be one truth for you and another for me. Such relativism will blind our judgements and make us less able to judge evidence impartially and objectively. But we ought to learn to view things as they are ....Hence, utility, workability and satisfactory result cannot be the test of truth. There are innumerable theories in religion, economic life, science, and other fields which have "worked" for a considerable length of time. We also know that untrue ideas can lead to what many people call "satisfactory" result. And certainly, too, some judgements cannot be pragmatically verified. And it must also be added that while beliefs that are true tend to work in the long run it is not necessarily the case that beliefs which work are therefore true. (pp.47-48)

The researcher quite agrees with Eboh (1995). This is as a result of the fact that if one follows the pragmatic view of truth, it will definitely lead to chaos. Thus, it enthrones the principle of 'anything goes' and leads to anarchism. It seems to the researcher that there is something objective about truth. The truth of an idea is not as changing as William James and other pragmatists claim. Capps (2019) articulates similar criticisms of pragmatic concept of truth. According to him:

One classic and influential line of criticism is that, if the pragmatic theory of truth equates truth with utility, this definition is (obviously!) refuted by the existence of useful but false beliefs, on the one hand, and by the existence of true but useless beliefs on the other (Russell 1910 [1994] and Lovejoy 1908a,b). In short, there seems to be a clear and obvious difference between describing a belief as true and describing it as useful (para. 42)

Obviously, that an idea is useful or workable does not in any way imply that it is true. In other words, workability or usefulness does not entail truthfulness. In fact, usefulness and truthfulness are not in any way synonymous. They are quite different concepts, and as such ought to be treated differently. Capps (2019) further articulates the basic objection to William James' pragmatic concept of truth and other pragmatic theories of truth thus:

One long-standing and still ongoing objection is that pragmatic theories of truth are anti-realist and, as such, violate basic intuitions about the nature and meaning of truth: call this "the fundamental objection". The source of this objection rests with the tendency of 
pragmatic theories of truth to treat truth epistemically, by focusing on verifiability, assertibility, and other related concepts. Some (see, e.g., Schmitt 1995; Nolt 2008) have argued that, by linking truth with verifiability or assertibility, pragmatic theories make truth too subjective and too dependent on our contingent ability to figure things out, as opposed to theories that, for example, appeal to objective facts as truth-makers. (para. 49)

The researcher quite agrees with Capps (2019) on the subjective implication of William James' pragmatic concept of truth. Truth is not something that is personal to an individual. It has a public character. For instance, the idea of theft is intrinsically and objectively bad. It cannot become good because it works for some people under certain circumstances. It is the argument of this article that some ideas are intrinsically and objectively true, while some are intrinsically and objectively false. Truth does not just 'happen' to an idea as William James claims. Also, the truth of an idea does not depend on its practical consequence. Truth remains a permanent quality of an idea. William James' pragmatic concept of truth gives room for chaos and anarchy in human life. Such an idea devalues the intrinsic value of truth, and thus leaves much to be desired.

\section{CONCLUSION}

This article has given detailed and critical attention to William James' pragmatic concept of truth. As it is obvious from the discourse, William James sees a deep relationship between truth and action, and thus emphasizes its practical consequence or implication. Thus, truth is not a fixed property of anything, and nothing could be said to be objectively true. James' pragmatic concept of truth is very controversial, and thus has been an object of severe criticism. This is as a result of the fact that James denied the objectivity of truth, and conceived truth from a relativistic perspective. It doesn't seem to the researcher that truth is a relative concept as William James claimed. His denial of the objectivity of truth is quite unacceptable as a result of its anarchistic implication. However, despite the shortcomings of William James' pragmatic concept of truth, he has made remarkable contributions to scholarship by bringing out the practical implications of truth, and extricating it from rationalistic tendency as well as dogmatism. 


\section{REFERENCES}

Capps, J., (2019) 'The pragmatic theory of truth', The stanford encyclopedia of philosophy, Edward N. Zalta (ed.), retrieved from URL=https://plato. Stanford .edu / archives/sum2019/entries/truth-pragmatic/.>) (04/02/2021)

Eboh, B. O., (1995) Basic issues in theories of knowledge, Enugu: Snaap Press.

James, W., (1991) Pragmatism, New York: Prometheus Books.

Jimoh, A. K., (2017) Certitude and doubt: A study guide in epistemology, 2nd Ed, Benin: Catholic Archdiocese of Benin Printing Press.

Legg, C. and Hookway, C., (2020) 'Pragmatism', The Stanford encyclopedia of philosophy, Edward N. Zalta (ed.), retrieved from URL=<https: //plato .stanford. edu/archives/fall2020/entries/pragmatism/>)(06/02/2021)

Maddux, H. C. and Donnect, D., (2015) John Dewey's pragmatism: Implications for reflection in service-learning, retrieved from https://files.eric.ed.gov/fultext/ EJ1118448.pdf ) (10/03/2021)

Pomerleau W. P. (n.d) 'William James (1842-1910)', Internet encyclopedia of philosophy, retrieved from https://iep.utm.edu/james-01(13/04/2021)

Stumpf, S. E., (1994) Philosophy history \& problems $5^{\text {th }}$ ed., New York: McGraw-Hill, Inc. 